\title{
The effectiveness of a pregnancy leaflet to promote health in Tshwane, South Africa
}

\begin{abstract}
Authors:
Susan C. Wright ${ }^{1}$

Titilayo T. Biya ${ }^{1}$

Majapi E. Chokwe

Affiliations:

${ }^{1}$ Adelaide Tambo School of Nursing Science, Tshwane University of Technology, Pretoria

Correspondence to:

Susan Wright

Email:

scdwright@gmail.com

Postal address:

PO Box 524, Auckland Park

2006, South Africa

\section{Dates:}

Received: 03 July 2013

Accepted: 20 June 2014

Published: 21 Nov. 2014

Republished: 25 Nov. 2014

How to cite this article:

Wright, S.C., Biya, T.T. \&

Chokwe, M.E., 2014, 'The

effectiveness of a pregnancy

leaflet to promote health

in Tshwane, South Africa',

Health SA Gesondheid 19(1),

Art. \#764,7 pages. http://

dx.doi.org/10.4102/hsag.

v19i1.764

Note:

Article republished with the corrected Berkman reference in-text.
\end{abstract}

\section{Copyright:}

C 2014. The Authors.

Licensee: AOSIS

OpenJournals. This work

is licensed under the

Creative Commons

Attribution License.
Read online:
Background: Pregnancy-related health education conveys basic information regarding healthy lifestyle choices and preventive healthcare in order to promote the health of the mother and foetus. Verbal education is supplemented frequently by means of healthpromotion leaflets. A pregnancy-related leaflet used in primary care clinics in Tshwane, South Africa titled: 'Are you pregnant or planning to have a baby?' was the focus of this research.

Objectives: The study had two objectives, the first of which was to explore whether the English pregnancy leaflet improved the knowledge of young female adults with regard to maintaining their health and preventing complications during pregnancy. The second objective was to explore whether the literacy level of the young adult female had an effect on the efficacy of the English pregnancy leaflet.

Method: The research design used was a pre-test post-test design. Two samples of 30 participants each, namely, a post-secondary and a tertiary sample, participated in the study. Self-report data were gathered with a questionnaire based on the leaflet. The quantitative data were analysed using descriptive statistics and a Pearson's chi-square test.

Findings: The findings indicated both samples' prior knowledge regarding health maintenance, showing that prevention of complications during pregnancy was almost nonexistent and that the pregnancy leaflet did not improve their knowledge to an extent where they would be informed and knowledgeable about their health during pregnancy.

Conclusion: An evidence base must be developed in order to support the development of behaviour changing material.

Agtergrond: Swangerskapsverwante gesondheidsopvoeding dra basiese inligting oor aangaande gesonde leefstylkeuses en voorkomende sorg om die gesondheid van moeder en fetus tydens swangerskap te bevorder. Verbale gesondheidsonderrig word dikwels versterk deur gedrukte inligtingstukke. 'n Swangerskapsverwante inligtingstuk tans in gebruik in primêre gesondheidsorgklinieke in Tshwane met die titel: 'Are you pregnant or planning to have a baby?' was die fokus van die studie.

Doelwitte: Die studie het twee doelwitte gehad, naamlik (1) om uit te vind of die Engelse inligtingstuk die kennis van jong volwasse vroue to so ' $n$ mate kon verbeter dat hulle in staat was om gesond te bly tydens hul swangerskap en komplikasies te voorkom, asook (2) om te bepaal of die geletterdheidsvlak van die jong volwasse vroue 'n invloed gehad het op die vermoë van die inligtingstuk om hul kennisvlakke te verhoog.

Metode: Die navorsingsontwerp was 'n voor-toets/na-toets ontwerp. Twee groepe van 30 deelnemers elk, 'n na-sekondêre onderrig en 'n tersiêre groep, het aan die studie deelgeneem. Data is deur self-rapportering ingesamel waar die deelnemers ' $n$ vraelys gebaseer op die pamflet voltooi het, voor en na blootstelling aan die inligtingstuk. Die data is met behulp van beskrywende statistiek en 'n Pearson's chi-kwadraat ontleed.

Resultate: Die bevindings dui daarop dat beide groepe baie min voorkennis aangaande gesondheid tydens swangerskap gehad het en dat die swangerskapsverwante inligtingstuk nie hul kennis tot so 'n mate verbeter dat hulle ingelig en in staat sou wees om gesond te bly tydens hul swangerskap nie.

Gevolgtrekking: Dit is belangrik dat navorsingsbewyse gebruik word in die ontwikkeling van gedragsveranderingsmateriaal.

\section{Introduction}

Pregnancy health education conveys basic information of healthy lifestyle choices and preventive healthcare to promote the health of the mother and foetus. However, it is common 
knowledge that verbal communication often fails, as the women can misunderstand or forget what they were taught. Verbal education requires supplementation with health-promotion leaflets (Zakrzewska et al. 1997:48). Kravdal (2004:177) reports that the expansion of health education through the use of health promotion leaflets reduces maternal mortality; however, women with underdeveloped skills in reading and writing will not gain as much information (Nutbeam 2006:264).

Health personnel often take for granted women's ability to read and understand health promoting materials. Similarly, women may find it difficult to communicate with health personnel because of a poor understanding of basic health terminology, minimal health knowledge and understanding of new information (Parker 2000:277). In research conducted in the United States of America regarding health literacy, the average educational level of an American adult is above 12th grade, but their average reading skill is between 8th- and 9th-grade levels, providing evidence that educational level does not equate to a person's literacy skill (Parker 2000:278).

Literacy levels have gained increasing importance in the healthcare environment because of the fact that nurses and other healthcare professionals use written health education materials, which often require reading levels higher than those of most people, as a major part of health promotion. As a result, 'clients and patients with low literacy will have difficulty understanding healthcare instructions and making appropriate healthcare decisions' (Boswell et al. 2004:61). Clients with a low literacy level often hide this fact because of the shame and low self-esteem associated therewith. Written material, such as health-promotion leaflets, should be in simple language aimed at lower than the 5 th-grade level. The use of easily understandable pictures is also encouraged (Parker 2000:281).

The South African report on confidential enquiries into maternal deaths (National Committee on Confidential Enquiries into Maternal Deaths [NCCEMD] 2007:3) identified the 'big five' causes of maternal death to be non-pregnancyrelated infections which are: Acquired Immunodeficiency Syndrome (AIDS) (43.7\%), complications of hypertension (15.7\%), obstetric haemorrhage (12.4\%), pregnancy-related sepsis $(9.0 \%)$ and pre-existing maternal disease (6.0\%). Nonpregnancy-related infections are the most common cause of maternal mortality in South Africa since 1999, with HIV being the major contributor (NCCEMD 2007:3). Counselling and voluntary HIV testing, particularly when performed early in puberty or pregnancy, offer benefits for HIV-positive women. Non-attendance and delayed attendance at the health institutions were the most common problems, [followed by] poor transport facilities, lack of healthcare facilities and lack of appropriately-trained staff' (NCCEMD 2007:4).

\section{Theoretical underpinning of the study}

The theoretical basis of the study is Pawlak's Health Literacy Model (Pawlak 2005), which focuses on the ability of an individual to acquire, process and understand the basic health information and services needed to make appropriate health decisions (Pawlak 2005:175). Low health literacy can lead to various adverse effects such as poor use of healthcare services, poor health status, poor compliance with treatment and medication, increased healthcare costs, lack of knowledge of health and increased hospitalisation. Health literacy determinants include age, genetics, language, race, ethnicity, education, employment, socioeconomic status and environment. The application of the model in the study is the focus on age and education in the ability of young female adults to gain knowledge from a health-promoting pregnancy-related leaflet.

\section{Motivation}

The motivation for the study was the high maternal mortality rate in South Africa. The level of maternal deaths in South Africa is increasing, not decreasing, and the Millennium Development Goal (MDG) target for 2015 is 38 maternal deaths per 100000 live births. According to the South African MDG Report of 2010, the baseline in 2001 was 369, increasing to 627 in 2007 (Statistics South Africa 2010:65). A compounding factor in the maternal mortality rate is the extent of low literacy in South Africa. Low literacy is a pervasive barrier for health promotion in South Africa, influencing healthcare quality and cost but, even more seriously, increasing premature mortality. Life expectancy in South Africa was reduced to 49.56 years in 2012 (Central Intelligence Agency 2014); the target for 2015 is 70 years (Statistics South Africa 2010:60).

Little or no research has been done regarding literacy levels, which serves to 'hide' the general low literacy level amongst South Africans. Support for this statement is provided in the 2011 census (Statistics South Africa 2012). Of the total South African population of just more than 51 million, $12.1 \%$ had a tertiary education and $28.5 \%$ had achieved an educational level of Grade 10 to Grade 12, leaving 60.4\% with an educational level below Grade 10. If the four-grade difference between highest school grade achieved and reading ability is subtracted (Wasserman, Wright \& Maja 2010), the majority of the South African population (60.4\%) reads at Grade 6 level and lower, resulting in low literacy despite academic achievement.

\section{Research question}

The research question for the study was thus: Does the English pregnancy leaflet improve the knowledge of young adult females to maintain their health and prevent complications during pregnancy and does the literacy level of the young adult female have an effect on the effectiveness of the leaflet?

\section{Purpose and objectives}

The purpose of this study is to reduce maternal complications during pregnancy by empowering young South African female adults with the knowledge to maintain 
their health when pregnant and prevent complications during pregnancy. The objective of the study was to:

- Explore whether the English pregnancy leaflet improved the knowledge of young adult females to maintain their health and prevent complications during pregnancy.

- Explore whether the literacy level of the young adult females has an effect on the effectiveness of the English Tshwane Municipality pregnancy leaflet.

\section{Research method and design \\ Setting}

The study was carried out in Pretoria West and Extension TT Soshanguve, both in Tshwane, a metropolitan municipality in Gauteng Province, South Africa. According to Statistics South Africa (2012), the population was just over 2.5 million people, of which young females comprised $42.1 \%$.

\section{Design}

The quantitative design chosen was a pre-test/post-test design which measures programme outcomes by comparing knowledge at the end of the programme (post) to a baseline (pre) (Maxfield 2001:4-8). The intervention was the exposure to the pregnancy leaflet.

\section{Population}

The target population for the study was adult females between 18 and 25 years of age. Two samples were chosen: one for literacy levels accepted for tertiary education and the second for completed secondary education, not necessarily at Grade 12 level. The justification for using the broad distinction of secondary and tertiary education is because these are the most frequently-used educational categories in the South African healthcare system. The sampling method was non-probability using convenience and purposive sample because of their availability and inclusion criteria. The motivation for the two samples was to explore whether the literacy level of the young female adult has an effect on the level of knowledge gained from the pregnancy leaflet. The inclusion criteria for the two samples were:

Sample $1(n=30)$, tertiary students (hereafter the 'tertiary sample'):

- young adult females between 18 and 25 years of age

- first year of tertiary study in a non-health-related discipline at Tshwane University of Technology

- secondary education completed in English

- no previous pregnancy

- a willingness to participate.

Sample $2(n=30)$, post-secondary education (hereafter the 'post-secondary sample'):

- young adult females between 18 and 25 years of age

- post-secondary education regardless of what grade was achieved

- not previously or currently registered for tertiary education
- secondary education completed in English

- no previous pregnancy

- a willingness to participate.

\section{Data collection}

Self-report data were gathered using a questionnaire based on the pregnancy leaflet which was developed by the researchers. Reliability and validity of the questionnaire were maintained by ensuring that the content of the questionnaire was based on the leaflet being researched and pre-tested before data gathering. In the questionnaire, closed and openended questions relating to all themes, sections and pictures in the leaflet were asked and included a demographic profile regarding the participant's age, school grade completed and home language. The questionnaire was pre-tested on a similar sample $(n=10)$ and no problems were identified. The time required to complete the questionnaire was less than 30 minutes. The data of the tertiary sample were gathered in a venue at Tshwane University of Technology. A venue for the post-secondary sample was negotiated with the group. The participants received an explanation of the data-gathering process and informed consent was signed to ensure that it was voluntary. The pre-test was done first and the post-test immediately after exposure to the intervention - the pregnancy leaflet.

\section{Data analysis}

The data were analysed using descriptive statistics and Pearson's chi-square (Brink 2006:19). An Excel (Microsoft ${ }^{\circledR}$ 2000) spreadsheet was used to code the data, with analysis using the Stata Statistical Software, v11 package (StataCorp LP, College Station, TX 2009). The interpretation was performed at a $95 \%$ confidence limit.

\section{Results \\ Demographic profile}

The majority $(76.7 \%)$ of the tertiary and post-secondary samples were older than 19 years of age. In the postsecondary sample, the majority of the participants (93.3\%) had attained a Grade 12 level of education. In the tertiary sample, the highest proportion spoke Setswana (23.2\%), followed by English (20.0\%), compared with the postsecondary sample where the highest was Setswana (40\%), followed by Sesotho.

\section{Pregnancy-related knowledge}

Table 1 illustrates the participants' knowledge of the signs of pregnancy.

As presented in Table 1, none of the participants in the tertiary sample knew about breast tenderness, nipple discolouration or breast tenderness pre-intervention, compared with 33.3\%, $23.3 \%$ and $33.3 \%$, respectively, post-intervention. These differences were significant. In terms of the post-secondary sample, although there was a slight improvement in all signs of pregnancy, the differences were not significant. 
An item in the leaflet explains when and why a pregnant woman should register for antenatal care early in the pregnancy. The tertiary sample improved from 56.7\% to $93.3 \%$; less than half $(46.7 \%)$ of the post-secondary sample reported before 12 weeks, compared with $80.0 \%$ post-intervention. For both samples, the difference was significant. A question was also asked regarding the reasons for early booking in pregnancy. Just over one quarter of the tertiary sample $(26.7 \%)$ initially included monitoring the pregnancy and prevention of complications as being a reason, compared with $53.3 \%$ post-intervention, which constituted a significant difference $(p=0.035)$. During the pre-test, only $16.7 \%$ of the post-secondary sample mentioned monitoring the pregnancy, which increased to $26.7 \%$ during the post-test. One third (33.3\%) listed prevention of complications, but in the post-test, the proportion of correct responses decreased to $26.7 \%$. The midwife's responsibilities were explained in the pregnancy leaflet, which helps the client identify the appropriate personnel to seek out for help in case of any problem. Table 2 presents the two samples' responses regarding their knowledge of what a midwife does during antenatal care.

As presented in Table 2, the tertiary sample participants' knowledge regarding the midwife's duties improved significantly, except for physical examination which remained the same $(6.7 \%)$ and monitoring of the pregnancy which only improved from $16.7 \%$ to $26.7 \%$. In the postsecondary sample, the participants' knowledge of three duties, namely, taking the medical history, doing a physical examination and monitoring the pregnancy, improved, but not significantly. What must be noted is that the preintervention knowledge of both groups was very low, in most instances below $10.0 \%$. The increase in the level of knowledge, although significant in most instances, was still low, below $30.0 \%$ for all categories except one, namely, the post-secondary sample's increase to $40.0 \%$ regarding blood testing.

Table 3 displays the participants' knowledge of the reasons to perform HIV testing during pregnancy.

As is presented in Table 3, 63.3\% of the tertiary sample knew, pre-intervention, of the need to prevent motherto-child transmission of HIV (PMTCT), compared with $80.0 \%$ post-intervention. A small group $(16.7 \%)$ indicated the possibility of treatment if diagnosed as HIV-positive pre-intervention, as compared with $20.0 \%$ post-test, which cannot be seen as a significant change. In the postsecondary sample, $63.3 \%$ knew that PMTCT was the main reason for HIV testing, compared with $80.0 \%$ postintervention, however, less than one quarter (23.3\%) knew about treatment for HIV and only a very small group (3.3\%) knew about infant feeding choices.

TABLE 1: Correct responses in terms of signs of pregnancy (\%).

\begin{tabular}{|c|c|c|c|c|c|c|c|c|c|c|}
\hline \multirow[t]{3}{*}{ Signs of pregnancy } & \multicolumn{4}{|c|}{ Tertiary $(N=30)$} & \multirow[t]{3}{*}{$p$-value } & \multicolumn{4}{|c|}{ Post-secondary $(N=30)$} & \multirow[t]{3}{*}{$p$-value } \\
\hline & \multicolumn{2}{|c|}{ Pre-intervention } & \multicolumn{2}{|c|}{ Post-intervention } & & \multicolumn{2}{|c|}{ Pre-intervention } & \multicolumn{2}{|c|}{ Post-intervention } & \\
\hline & $n$ & $\%$ & $n$ & $\%$ & & $n$ & $\%$ & $n$ & $\%$ & \\
\hline Missed period & 16 & 53.3 & 23 & 76.6 & 0.058 & 16 & 53.3 & 19 & 63.3 & 0.432 \\
\hline Breast tenderness & 0 & 0.0 & 10 & 33.3 & $0.001 *$ & 1 & 3.3 & 4 & 13.3 & 0.161 \\
\hline Nausea & 10 & 33.3 & 17 & 53.3 & 0.069 & 8 & 26.7 & 11 & 36.7 & 0.404 \\
\hline Nipple discolouration & 0 & 0.0 & 7 & 23.3 & $0.005 *$ & 0 & 0.0 & 1 & 3.3 & 0.313 \\
\hline Growing stomach & 0 & 3.3 & 8 & 26.7 & $0.011 *$ & 1 & 3.3 & 3 & 10.0 & 0.301 \\
\hline Frequent urination & 1 & 3.3 & 4 & 13.3 & 0.161 & 0 & 0.0 & 3 & 10.0 & 0.076 \\
\hline
\end{tabular}

*, Statistically-significant result; level of significance $p<0.05$

TABLE 2: Samples' responses to a midwife's responsibilities during antenatal care.

\begin{tabular}{|c|c|c|c|c|c|c|c|c|c|c|}
\hline \multirow[t]{3}{*}{ Midwife's responsibilities } & \multicolumn{4}{|c|}{ Tertiary $(n=30)$} & \multirow[t]{3}{*}{$p$-value } & \multicolumn{4}{|c|}{ Post-secondary $(n=30)$} & \multirow[t]{3}{*}{$p$-value } \\
\hline & \multicolumn{2}{|c|}{ Pre-intervention } & \multicolumn{2}{|c|}{ Post-intervention } & & \multicolumn{2}{|c|}{ Pre-intervention } & \multicolumn{2}{|c|}{ Post-intervention } & \\
\hline & $n$ & $\%$ & $n$ & $\%$ & & $n$ & $\%$ & $n$ & $\%$ & \\
\hline Medical history & 1 & 3.3 & 5 & 16.7 & 0.085 & 2 & 6.7 & 5 & 16.7 & 0.228 \\
\hline Blood pressure & 2 & 6.7 & 8 & 26.7 & $0.038^{*}$ & 0 & 0.0 & 5 & 16.7 & $0.020 *$ \\
\hline Urine test & 1 & 3.3 & 8 & 26.7 & $0.011 *$ & 2 & 6.7 & 9 & 30.0 & $0.020 *$ \\
\hline Weighing & 1 & 3.3 & 5 & 16.7 & 0.085 & 0 & 0.0 & 6 & 20.0 & $0.010 *$ \\
\hline Blood test & 0 & 0.0 & 7 & 23.3 & $0.005^{*}$ & 6 & 20.0 & 12 & 40.0 & $0.020 *$ \\
\hline Physical examination & 2 & 6.7 & 2 & 6.7 & 1.000 & 3 & 10.0 & 4 & 13.3 & 0.688 \\
\hline Monitor pregnancy & 5 & 16.7 & 8 & 26.7 & 0.347 & 4 & 13.3 & 5 & 16.7 & 0.718 \\
\hline
\end{tabular}

*, Statistically-significant result; level of significance $p<0.05$

TABLE 3: Participants' reasons for HIV testing during pregnancy (\%).

\begin{tabular}{|c|c|c|c|c|c|c|c|c|c|c|}
\hline \multirow[t]{3}{*}{ Reasons for HIV testing } & \multicolumn{4}{|c|}{ Tertiary $(n=30)$} & \multirow[t]{3}{*}{$p$-value* } & \multicolumn{4}{|c|}{ Post-secondary $(n=30)$} & \multirow[t]{3}{*}{$p$-value* } \\
\hline & \multicolumn{2}{|c|}{ Pre-intervention } & \multicolumn{2}{|c|}{ Post-intervention } & & \multicolumn{2}{|c|}{ Pre-intervention } & \multicolumn{2}{|c|}{ Post-intervention } & \\
\hline & $n$ & $\%$ & $n$ & $\%$ & & $n$ & $\%$ & $n$ & $\%$ & \\
\hline РMTCT & 19 & 63.3 & 24 & 80.0 & 0.152 & 19 & 63.3 & 24 & 80.0 & 0.152 \\
\hline Treatment if positive & 5 & 16.7 & 6 & 20.0 & 0.739 & 7 & 23.3 & 6 & 20.0 & 0.754 \\
\hline Feeding choices & 0 & 0.0 & 3 & 10.0 & 0.076 & 1 & 3.3 & 2 & 6.7 & 0.554 \\
\hline
\end{tabular}

PMTCT, prevention of mother-to-child transmission of HIV.

$*$, No statistically-significant results; level of significance $p<0.05$ 
Table 4 presents the participants' knowledge regarding danger signs in pregnancy.

As is illustrated in Table 4, 6.7\% of the tertiary sample knew about vomiting as a danger sign in pregnancy, compared with $80.0 \%$ post-intervention. Likewise, only $3.3 \%$ of the participants initially knew about diarrhoea as a danger sign, but this increased to $30.0 \%$ post-intervention. Vaginal discharge and severe headache were known of by $0.0 \%$ and $6.7 \%$ pre-intervention, increasing to $16.7 \%$ and $26.7 \%$, respectively, post-intervention. The differences in both pre- and post-test scores of vomiting, diarrhoea, vaginal discharge and severe headache were significant $(p=0.000$, $0.006,0.020,0.038$, respectively). In the post-secondary sample, $3.3 \%$ added vaginal discharge as a danger sign, but this increased to $20.0 \%$ post-intervention. The difference in the pre- and post-test scores for this was significant $(p=0.044)$.

Table 5 summarises the correct interpretation of pictures used in the pregnancy leaflet.

Both samples generally interpreted the pictures better than they understood the written words in the leaflet (Table 5). The tertiary sample had a better average score $(64.9 \%)$ preintervention than did the post-secondary sample (52.5\%). It is of concern that the HIV symbol was the least understood of all the pictures (tertiary sample 33.3\%; post-secondary sample $20.0 \%$ ). Three of the post-secondary samples were significantly different, including the picture of the stages of development of the foetus, a stressed woman and a midwife measuring blood pressure. The pictures best understood in the tertiary sample were the one indicating No Alcohol $(90.0 \%)$ as well as that showing a woman exercising $(90.0 \%)$, whereas in the post-secondary sample, it was the woman exercising (76.7\%).

\section{Summary of the study's findings}

To highlight the findings, two different summaries are provided:

- Based on an evaluation of having a significant difference between the pre- and post-intervention findings, the post-secondary sample gained less knowledge from the leaflet $(21.1 \%)$ compared with $39.5 \%$ for the tertiary sample.

- A summary was made of responses to questions in both samples, where the knowledge level of the pre-test value was less than $20.0 \%$ and post-test value less than $30.0 \%$. There were 38 questions in the questionnaire. For the tertiary sample there were 22 questions (57.9\%) complying with the criteria; and for the post-secondary sample, 23 questions (60.5\%). It is clear that the young adult females' basic knowledge regarding health

TABLE 4: Knowledge regarding the danger signs in pregnancy.

\begin{tabular}{|c|c|c|c|c|c|c|c|c|c|c|}
\hline \multirow[t]{3}{*}{ Danger signs in pregnancy } & \multicolumn{4}{|c|}{ Tertiary $(n=30)$} & \multirow[t]{3}{*}{$p$-value } & \multicolumn{4}{|c|}{ Post-secondary $(n=30)$} & \multirow[t]{3}{*}{$p$-value } \\
\hline & \multicolumn{2}{|c|}{ Pre-intervention } & \multicolumn{2}{|c|}{ Post-intervention } & & \multicolumn{2}{|c|}{ Pre-intervention } & \multicolumn{2}{|c|}{ Post-intervention } & \\
\hline & $n$ & $\%$ & $n$ & $\%$ & & $n$ & $\%$ & $n$ & $\%$ & \\
\hline Vomiting & 2 & 6.7 & 24 & 80.0 & $0.000 *$ & 6 & 20.0 & 6 & 20.0 & 1.000 \\
\hline Diarrhoea & 1 & 3.3 & 9 & 30.0 & $0.006 *$ & 0 & 0.0 & 1 & 3.3 & 0.313 \\
\hline Severe abdominal pain & 4 & 13.3 & 5 & 16.7 & 0.718 & 4 & 13.3 & 2 & 6.7 & 0.389 \\
\hline Vaginal discharge & 0 & 0.0 & 5 & 16.7 & $0.020 *$ & 1 & 3.3 & 6 & 20.0 & $0.044 *$ \\
\hline Vaginal bleeding & 14 & 46.7 & 18 & 60.0 & 0.301 & 13 & 43.3 & 16 & 53.3 & 0.438 \\
\hline Watery discharge & 0 & 0.0 & 2 & 6.7 & 0.150 & 1 & 3.3 & 2 & 6.7 & 0.554 \\
\hline Severe headache & 2 & 6.7 & 8 & 26.7 & $0.038^{*}$ & 2 & 6.7 & 2 & 6.7 & 1.000 \\
\hline Dizziness & 0 & 0.0 & 3 & 10.0 & 0.076 & 2 & 6.7 & 4 & 13.3 & 0.389 \\
\hline Nose bleeding & 0 & 0.0 & 3 & 10.0 & 0.076 & 1 & 3.3 & 1 & 3.3 & 1.000 \\
\hline Tiredness & 0 & 0.0 & 1 & 3.3 & 0.313 & 0 & 0.0 & 1 & 3.3 & 0.313 \\
\hline
\end{tabular}

*, Statistically-significant result; level of significance $p<0.05$

TABLE 5: Summary of correct interpretation of pictures used in the pregnancy leaflet.

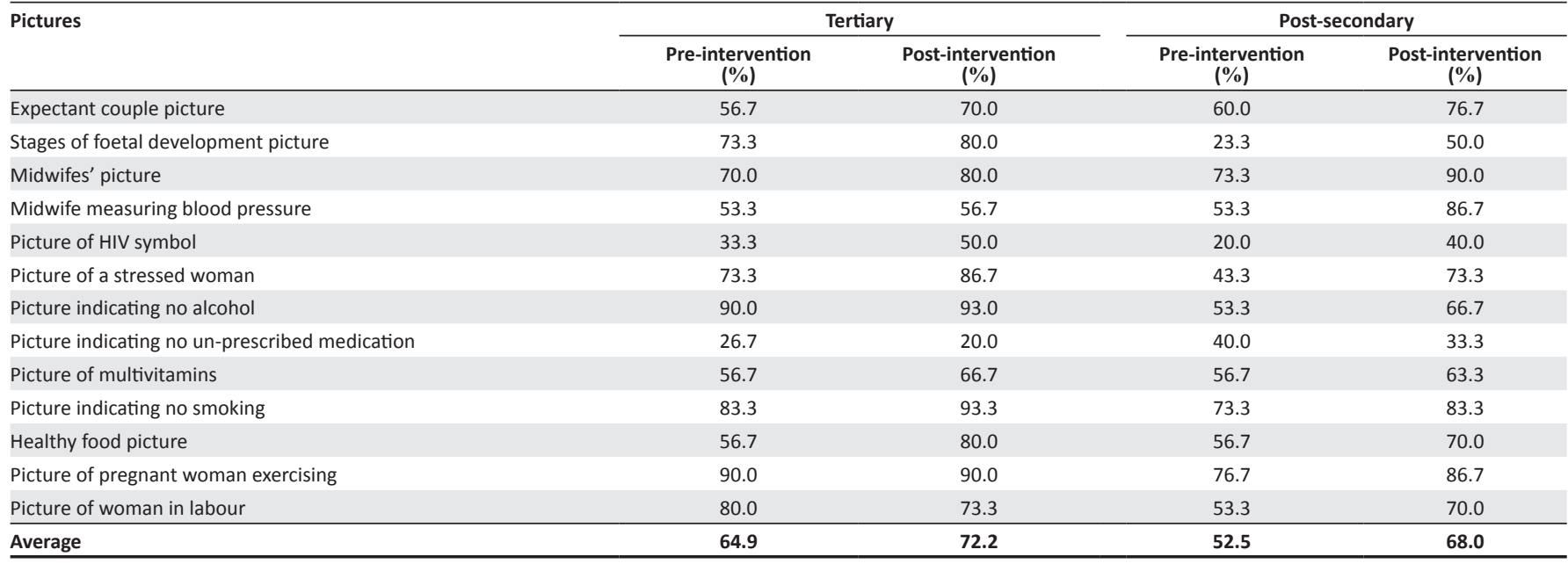


maintenance and prevention of complications during pregnancy was almost non-existent and the pregnancy leaflet did not improve their knowledge to such an extent that they would be both informed and knowledgeable about their health during pregnancy.

\section{Ethical considerations}

Participation was voluntary and informed consent obtained before participation in the study. Only those who met the criteria for participation in the study were approached. In addition, the participants' anonymity and confidentiality were protected.

The research proposal was approved by the Research Ethics Committee of Tshwane University of Technology (Reference number: 2009/06/002) and the City of Tshwane, Health Services Division prior to commencement.

\section{Reliability and validity \\ Reliability}

Reliability was assured by applying the following measures:

- Instrument: A pilot test of the questionnaire prior to data gathering was done and was not included in the final data.

- Language: The questionnaire was in English and both samples completed their secondary education in English.

- History and maturation: Both were prevented by administering the leaflet and post-test immediately after the pre-test.

\section{Validity}

Validity was assured though content validity. The pregnancy leaflet was the basis for the questionnaire.

\section{Discussion}

The lack of knowledge regarding the signs of pregnancy (Table 1) and the danger signs during pregnancy (Table 4) is concerning. In both topics, the pregnancy leaflet did not improve the knowledge of the young adult females to a level where they would be able to make informed decisions when pregnant. Knowledge of obstetric danger signs is a strategy aimed at reducing complications in pregnancy. Kabakyenga et al. (2011) emphasise that pregnancy is inherently risky; therefore, women should be made aware of the danger signs of obstetric complications during pregnancy, delivery and postpartum. Being knowledgeable will empower women to make prompt decisions to seek immediate help. In research conducted in Tanzania, regarding awareness of danger signs of obstetric complication $(n=1118)$, only $26.0 \%$ of women knew at least one danger sign during pregnancy, $23.0 \%$ during delivery and $40 \%$ after delivery; few women knew three or more danger signs (Pembe et al. 2009:16).

Antenatal care provides the ideal opportunity to inform pregnant women about pregnancy, childbirth and care of the newborn, allowing them to make informed choices which contribute to a good pregnancy outcome (Begley et al. 2001:90; Renkert \& Nutbeam 2001:382). In South Africa, antenatal care is midwife-led and, from the findings of the study, less than $20 \%$ (in most instances, less than $10.0 \%$ ) of both samples knew what a midwife does during antenatal care (Table 2). This lack of knowledge regarding the role of the midwife may be a factor which underpins the general lack of antenatal attendance in South Africa and more research is required.

The knowledge of HIV and the reasons for testing are important to the young adult females since they are representative of one of the groups who are at the highest risk of infection (Allen, Simelela \& Makubalo 2000:10). In a national household survey conducted in South Africa in $2003,15 \%$ of young women and almost $5 \%$ of young men between 15 and 24 years are living with HIV (Hendriksen et al. 2007:1241), therefore, HIV education should be included in sex education lessons from puberty. Regular use of voluntary HIV counselling and testing could provide both necessary information and potential solutions to risky scenarios for young adults, whether or not they are infected with HIV (Hendriksen et al. 2007:1241).

In the current study, even with the broad categories of secondary and tertiary education, the post-secondary sample gained less knowledge from the leaflet. Berkman et al. (2004:6) wrote that low literacy affects health literacy, adversely impairing the person's ability to function in the healthcare environment; it is associated with poor understanding of written or spoken health advice. Health literacy is the skill needed to function in a health setting and goes beyond simple reading ability; it involves the ability to understand instructions on prescriptions, appointment slips, health education and the ability to make informed decisions concerning one's health (Scudder 2006:29).

\section{Limitations}

The two samples (tertiary and post-secondary) were not representative of the tertiary universities and post-secondary youth in Gauteng. The sampling method used for the study was convenience sampling, thus the findings cannot be generalised. During the study, no measurement was taken of the literacy level required to read the pregnancy leaflet.

\section{Recommendations}

The study generated some answers regarding the prevention of complications during pregnancy from young adult females and also generated more questions requiring further research:

- The level of low literacy and low health literacy amongst patients in antenatal clinics in Gauteng should be measured in order to raise awareness and to inform the development of written health education material aimed at an educational grade lower than the 6th grade.

- Research should be done to investigate the readability of all health education materials used in antenatal clinics. 
- Further study, using other contexts throughout South Africa, is needed so as to provide representative findings in terms of knowledge gained from health promotion materials used in antenatal clinics.

\section{Conclusion}

This study explored the effectiveness of an English pregnancy leaflet with regard to promoting health and increasing health literacy regarding pregnancy. Being exposed to the leaflet did not improve the participant's knowledge regarding pregnancy-related matters. The leaflet did, however, expose the very low level of knowledge that young adult females have regarding health in pregnancy. A question could be asked about the evidence base that informed the development of this leaflet. The importance of reducing the maternal mortality rate mandates the development of evidence-informed health education material.

\section{Acknowledgements Competing interests}

The authors declare that they have no financial or personal relationship(s) that may have inappropriately influenced them in writing this article.

\section{Authors' contributions}

S.C.W. (Tshwane University of Technology) and T.T.B. (Tshwane University of Technology) were responsible with the conceptualisation, proposal development, data gathering, data analysis and scientific writing. M.E.C. (Tshwane University of Technology) assisted with conceptualisation, proposal development and scientific writing.

\section{References}

Allen, D.M., Simelela, P.N. \& Makubalo, L., 2000, 'Epidemiology of HIV/AIDS in South Africa', The Southern African Journal of HIV Medicine 1(1), 9-11.
Begley, C., Devane, D., Clarke, M., McCann, C., Hughes, P., Reilly, M. et al., 2001, 'Comparison of midwife-led and consultant-led care of healthy women at low risk of childbirth complications in the Republic of Ireland: a randomised trial', BMC Pregnancy \& Childbirth 11, 85.

Berkman, N.D., Dewalt, D.A., Pignone, M.P., Sheridan, S.L., Lohr, K, N., Lux, L. et al., 2004, Evidence report/Technology assessment No. 87. Literacy and health outcomes, Agency for Healthcare Research and Quality, Rockville.

Boswell, C., Cannon, S., Aung, K. \& Eldridge, J., 2004, 'An application of health literacy research', Applied Nursing Research 17(1), 61-64.

Brink, H.I., 2006, Fundamentals of research methodology for health care professionals, 2nd edn., Juta and Company, Ltd., Cape Town.

Central Intelligence Agency, 2014, The World Factbook. South Africa: Life expectancy at birth (years), viewed 19 September 2014, from https://www.cia.gov/library/ publications/the-world-factbook/fields/2102.html\#main-content

Hendriksen, E.S., Pettifor, A., Lee, S.J., Coates, T.J. \& Rees, H.V., 2007, 'Predictors of condom use among young adults in South Africa: The Reproductive Health and HIV Research Unit National Youth Survey', American Journal of Public Health 97(7) 1241-1248.

Kabakyenga, J.K., Östergren, P-O., Turyakira, E. \& Pettersson, K.O., 2011, 'Knowledge of obstetric danger signs and birth preparedness practices among women in rural Uganda', Reproductive Health Journal 8, 33.

Kravdal, O., 2004, 'Child mortality in India: The community-level effect of education' Population Studies 58(2), 177-192.

Maxfield, M.G., 2001, Guide to frugal evaluation for criminal justice, viewed 12 September 2010, from http://www.ncjrs.gov/pdffiles1/nij/187350.pdf

National Committee on Confidential Enquiries into Maternal Deaths, 2007, Saving mothers 2005-2007: Fourth report on confidential enquiries into maternal death in South Africa, viewed 23 August 2014, from http://www0.sun.ac.za/ruralhealth/
ukwandahome/rudasaresources2009/DOH/savingmothers\%2005-07\%5B1\%5D.pdf

Nutbeam, D., 2006, 'Health literacy as a public health goal: A challenge for contemporary health education and strategies into the 21st century', Health Promotion International 15(3), 259-267.

Parker, R., 2000, 'Health literacy: A challenge for American patients and their health care providers', Health Promotion International 15(4), 277-283.

Pawlak, R., 2005, 'Economic considerations of health literacy', Nursing Economics 23(4), 173-180.

Pembe, A.B., Urassa, D.P., Carlstedt, A., Lindmark, G., Nyström, L. \& Darj, E., 2009, 'Rural Tanzanian women's awareness of danger signs of obstetric complications', BMC Pregnancy \& Childbirth 9, 12.

Renkert, S. \& Nutbeam, D., 2001, 'Opportunities to improve maternal health literacy through antenatal education: An exploratory study', Health Promotion International 16(4), 381-388.

Scudder, L., 2006, 'Words and well-being: How literacy affects patients health', The Journal for Nurse Practitioners 2(1), 28-35.

Statistics South Africa, 2010, Millennium development goals: country report 2010, viewed 19 September 2014, from http://www.statssa.gov.za/news_archive/Docs/ MDGR_2010.pdf

Statistics South Africa, 2012, Census 2011: highlights of key results, viewed 03 Apri 2013, from http://www.statssa.gov.za/Census2011/Products/Census_2011 Methodology_and_Highlights_of_key_results.pdf

Wasserman, Z., Wright, S.C.D. \& Maja, T.M., 2010, 'Assessment of the English literacy level of patients in primary health care services of Tshwane, Gauteng Province: Part 2', Health SA Gesondheid 15(1), Art. \#469, 6 pages.

Zakrzewska, J.M., Leeson, R.M.A., Mcluskey, M. \& Vickers, M., 2008, 'The development of patient information leaflets. Care of the mouth after radiotherapy', Gerodontology 14(1), 48-53. 